\title{
Paulus se gewetenskonsep 1
}

P R Bosman

(UP)

\section{ABSTRACT}

\section{Paul's concept of conscience}

This survey article introduces the reader to Paul's concept of conscience via an analysis of the word ouveionols in his letters. It is argued that Paul uses the word within an inherited conceptual framework, but that he also introduces significant changes. The concept is basically understood as an inner monitor which spontaneously registers lack of integrity and discrepancies between thoughts, words and deeds. As an aspect of man's rational make-up, the conscience reacts on the basis of knowledge available to the individual, and plays the role of witness within a metaphorical inner court of law. Brief observations on how Paul's concept of conscience interacts with other aspects of his thinking conclude the paper.

In hierdie oorsig word Paulus se gewetenskonsep aan die hand van die

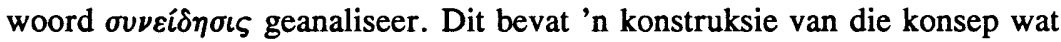

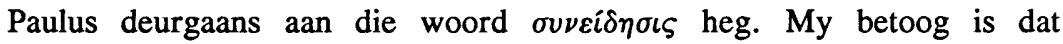

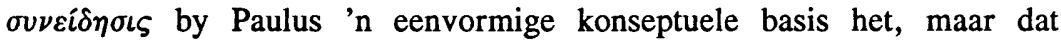
verskillende aspekte van die konsep in verskillende kontekste op die voorgrond tree. Paulus behou die tradisionele konseptuele raamwerk van die oúvoı $\alpha$ woordgroep, maar voer ook betekenisvolle vernuwings in die woordgebruik in.

Wat sou vandag nog die relevansie wees van 'n tekstuele, filologiese ondersoek na die gewetenskonsep by Paulus? Na my mening is die twee belangrikste beweegredes vir so 'n ondersoek die volgende:

(i) Dit is onteenseglik die apostel Paulus wat aan die gewetenskonsep statuur binne die Christelike teologie besorg het, ten spyte daarvan dat die konsep nie in sy eie teologiese denke sentraal staan nie. Die HebreeusJoodse tradisie ken geen ekwivalente begrip nie, en ook die Jesusoorleweringe toon geen blyke daarvan dat Jesus sodanige begrip gebruik het nie. Dit was Paulus - die apostel op die ontmoetingspunt van die Joodse en Grieks-Romeinse kultuurwêrelde - wat een van die mees vrugbare en mees besproke konsepte aan die Christendom en die Westerse etiek bekendgestel het. 
(ii) Daar is egter ook 'n rede vir so 'n ondersoek wat breër strek as die teologiese dissiplines. Vanuit 'n filologiese oogpunt beoordeel, is die gewete so 'n ontwykende en moeilik definieerbare begrip omdat die moderne konsep so 'n lang en ingewikkelde ontwikkelingsgeskiedenis het. Daarom sal ondersoeke na die konsep se oorspronklike ontstaansbodem vir moderne nadenke relevant bly.

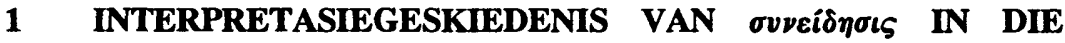 PAULUSBRIEWE}

Daar is al dikwels en deeglik oor Paulus se gebruik van die woord

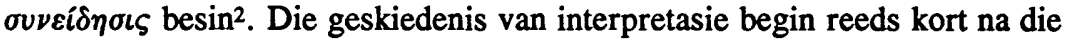
vroegste bundeling van Paulus se korrespondensie. Vroeë kommentare op die Paulusbriewe het die verdere ontwikkeling van die konsep diepgaande

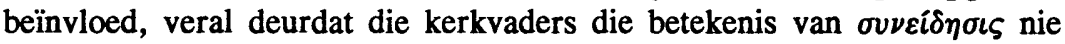
uit die geskrifte van Paulus afgelei het nie, maar by populêre en filosofiese gebruike van die Griekse sowel as de Latynse terme gaan haal het ${ }^{3}$. Gedurende die Middeleeue ontstaan daar geleidelik 'n teologiese tradisie waarin die gewete met die natuurreg verbind word: die sunderesis ${ }^{4}$ verteenwoordig die ingebore, onverdorwe vermoë van die mens om tussen goed en kwaad te onderskei; die conscientia sorg vir die praktiese toepassing van die sunderesis se aandrange en beginsels.

By Luther begin ' $n$ nuwe fase in die interpretasiegeskiedenis. Op grond van sy lees van die Bybelse tekste verwerp Luther die skolastiese opvattings van sy tyd en plaas die konsep binne sy eie teologiese raamwerk: die gewete word die kernelement van die indiwidu voor God, waardeur die mens deur die veroordelende wet en die vertroostende evangelie aangespreek word. Die "slegte gewete" bring God self tot openbaring in die mens en is die eerste stap tot regverdigmaking; die "goeie gewete" is sinoniem met die ervaring van God se verlossende genades. Na die Aufklärung word die gewete egter sy teologiese kleed ontneem en herbeskryf in terme van natuurlike instink, as die produk van opvoeding en samelewing, en op veel ander maniere 6 . Vanaf die tweede helfte van die negentiende eeu word vir die eerste keer werklik erns gemaak met die woordgebruik in die Nuwe Testament; veral die studie van Martin Kähler staan uit ${ }^{7}$. Kähler skryf 'n geskiedenis van die begrip in die antieke wêreld om sodoende Paulus se gebruik beter te verstaan. Op grond van sy bevindinge verwerp hy enige interpretasie van die gewete by die heidenapostel as vox dei of as antisiperend8: vir Paulus is die gewete deurgaans 'n suiwer antropologiese, suiwer retrospektiewe verskynsel. $\mathrm{Na}$ 
Kähler het verskeie geleerdes gedurende hierdie eeu aan die problematiek van Paulus se gewetenskonsep bly slyp ${ }^{9}$. Uitstaande studies van die afgelope halwe eeu is dié van C A Pierce, J Stelzenberger en H-J Eckstein $^{10}$, terwyl vele ander geleerdes op kleiner skaal tot die diskussie bygedra het ${ }^{11}$. Die bestaande navorsing werp veral drie vrae op:

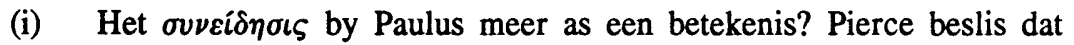
die woord se basiese betekenis in die antieke Griekse literatuur - 'n bepaalde soort pyn wat volg op oortreding - in die Nuwe Testament behoue gebly het ${ }^{12}$. Daarteenoor onderskei Stelzenberger nie minder nie as nege verskillende betekenisse in die Nuwe Testament, ses daarvan in die Paulusbriewe: "bewustheid as getuie" (Rom 9:1; 2 Kor 1:12), "innerlike verpligting" (Rom 13:5), "religieus-sedelike oordeelsvermoë" (1 Kor 8:10, 12 ; 10:25, 27-29; 2 Kor 4:2; 5:11), die "eintlike morele gewete" (Rom 2:15), die "goeie gewete" (1 Kor 4:4) en die "slegte gewete" (1 Kor $8: 7)^{13}$. Na onbevredigde reaksie op Stelzenberger se oplossing14, wend Ecktein in 1983 'n hernude poging aan om 'n uniforme betekenis van die

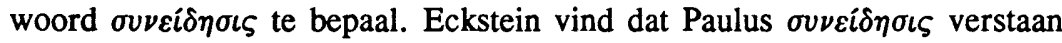
as 'n "Instanz" wat die verskillende gewetensfunksies veroorsaak en in werking stel. Hy ondervind egter probleme om sy eie voorstel konsekwent

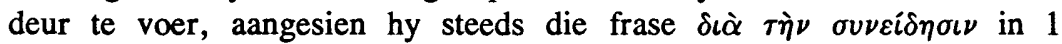
Korintiërs 10 as afsonderlike geval moet hanteer ${ }^{15}$.

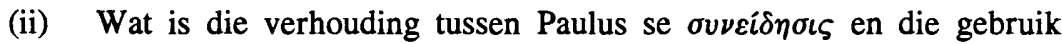
van die woord (asook van die Latynse ekwivalent conscientia) in buiteBybelse literatuur voor en kontemporêr aan die Nuwe Testament? Stelzenberger se voorstel dat daar 'n "prinzipielle Scheidewand" tussen Bybelse en nie-Bybelse gebruike van die woord veronderstel moet word, het nie wye byval gevind nie ${ }^{16}$. Aan die ander kant het Pierce skynbaar enige ontwikkeling in betekenis geïgnoreer. Hoewel die struktuur van Eckstein se studie suggereer dat hy 'n ontwikkelingslyn vanaf ouer gebruike van die oúvoเ $\delta \alpha$ woordgroep na dié van Paulus veronderstel ${ }^{17}$, bly hy ongelukkig vaag oor hoe die ontwikkeling verloop het. 'n Bevredigende oplossing moet sowel raakpunte met ouer gebruikswyses as nuwe assosiasies by Paulus aantoon.

(iii) Hoe word Paulus se gewetenskonsep deur die taal- en konseptuele wêreld van sy tyd bepaal? Hoewel die woord "gewete" steeds die beste vertaalekwivalent vir die antieke konsep bly18, moet ons Paulus se assosiasies aan die woord baie deeglik ontleed om te verhoed dat ons 
eenvoudig ons eie, moderne konsepsie in die apostel se gebruik van

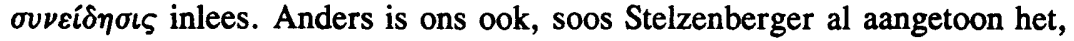
genoodsaak om allerlei interpretatiewe eierdanse uit te voer om maar net die moderne gewetenskonsep in die Paulusbriewe te probeer terugvind ${ }^{19}$.

\section{VOORKOMSTE VAN $\sigma \nu \varepsilon i ́ \delta \eta \sigma \iota \varsigma$ IN DIE PAULUSBRIEWE}

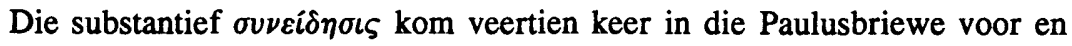
wel slegs in die Romeinebrief en die Korintiese korrespondensie ${ }^{20}$. Dit word deurgaans van 'n lidwoord vergesel. Dit is opmerklik dat Paulus,

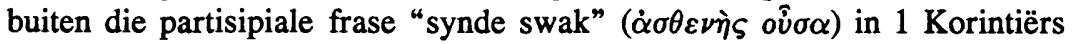

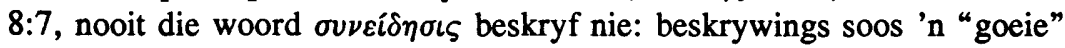
of 'n "rein" gewete wat ons in die res van die Nuwe Testament vind21 is in die onbetwiste Paulusbriewe afwesig.

Die woord kom gekonsentreerd voor in die twee perikope waarin Paulus die offervleis problematiek bespreek (1 Kor 8:1-6 en 1 Kor 10:23$11: 1)$. Drie van die vyf voorkomste in 1 Korintiërs 10 is in die moeilik interpreteerbare kombinasie met die voorsetsel $\delta \iota \alpha ́$. Dié frase word in Romeine 13:5 herhaal. ' $n$ Verdere herhalende kenmerk is die stam $\mu \alpha \rho \tau \nu \rho$ -

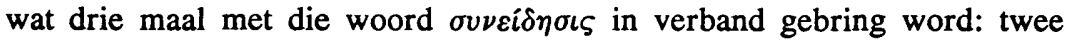
maal word $\sigma u \nu \varepsilon i \delta \eta \sigma \iota \varsigma$ gebruik as subjek van die werkwoord $\sigma \nu \mu \mu \alpha \rho \tau \nu \rho \varepsilon \hat{\nu} \nu$ (Rom $2: 15 ; 9: 1$ ) en een maal kom die stam in die vorm $\mu \alpha \rho \tau u ́ \rho \iota 0 \nu$ voor,

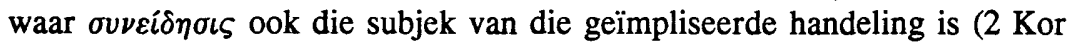
$1: 12)$.

\section{DIE $\sigma u ́ \nu o \iota \delta \alpha$ WOORDGROEP}

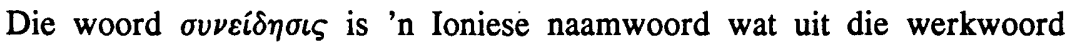
$\sigma v \nu o \iota \delta \alpha$ gevorm is. Op sy beurt is oúvot $\alpha$ saamgestel uit die voorsetsel $\sigma u ́ \nu$ (met, saam met) en die werkwoord oî $\delta \alpha$ (om te weet). Lúvol $\delta \alpha$ beteken dus "om mee te weet" en kom reeds in sesde eeuse Griekse literatuur met

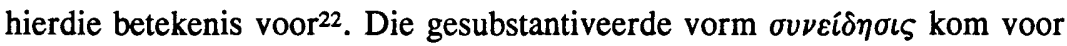
in ' $n$ fragment van die vyfde eeuse filosoof Demokritos ${ }^{23}$ maar is baie skaars in die voor-Christelike era: voor Paulus kom dit maar 'n handjievol kere voor in die geskrifte van die historiograwe Diodoros van Sicilië en Dionisios van Halikarnassos ${ }^{24}$. In hierdie vroeë fase van die woord se

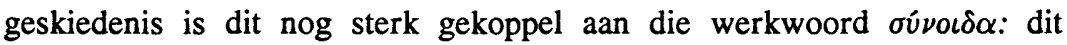
verwys na 'n bepaalde "medewete" wat byvoorbeeld deur samesweerders in 'n komplot met mekaar gedeel word. Dit kan ook verwys na die gedeelde wete tussen 'n oortreder en 'n tweede of derde persoon, wat die oortreder skaam, skuldig en onrustig laat voel. 
Heel vroeg reeds was die Grieke daarvan bewus dat jy ook "met jouself" van iets bewus kan wees, veral as jy een of ander oortreding begaan het. Dit het daartoe gelei dat die werkwoordelike frase "ek weet met myself van iets sleg/verkeerd wat ek gedoen het” in die omgangstaal bloot "ek weet met myself" kon word25. Later is die naamwoorde $\sigma u \nu \varepsilon i \delta \eta \sigma \iota \varsigma$ en $\sigma u \nu \varepsilon \iota \delta o ́ \varsigma$ gebruik om te verwys na hierdie skuldige "wete met myself” dat ek iets slegs gedoen het. Die antieke konsep in die vroeë gebruiksfase kan dus afgebaken word tot (i) die negatiewe en retrospektiewe aspek van die gewete, omdat dit iets is wat slegs ontstaan ná en na aanleiding van 'n oortreding van een of ander aard26; (ii) 'n werkwoordelike aspek, aangesien dit aanvanklik nie 'n psigiese entiteit nie, maar 'n denkhandeling verteenwoordig 27 .

Wanneer Paulus in die middel van die eerste eeu $\mathrm{nC}$ die term

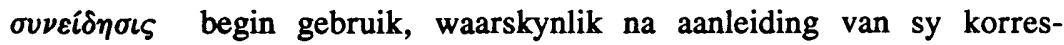
pondensie met die Korintiese Christene ${ }^{28}$, het die konseptuele ontwikkeling reeds weer 'n ent gevorder. 'n Tussenfase kan gesien word in die wyse waarop die Alexandryns-Joodse filosoof Philo die sinonieme naamwoord

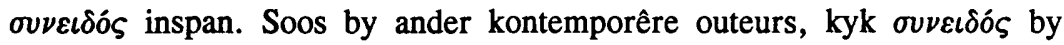
Philo steeds meestal terug na 'n handeling wat die besitter daarvan self begaan het en self as negatief beskou ${ }^{29}$. By Philo begin die woord egter verwys na 'n innerlike entiteit, 'n komponent in die samestelling van die siel. Dit is nie meer net iets wat insidenteel en na aanleiding van 'n bepaalde gebeurtenis ontstaan nie, maar 'n permanente onderdeel van die menslike innerlike ${ }^{30}$. Die metaforiek rondom Philo se $\sigma \nu \nu \varepsilon \iota \delta o ́ s$ was baie

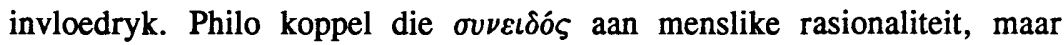
maak sterk gebruik van 'n metaforiese innerlike geregshof. Die $\sigma v \nu \varepsilon \imath \delta o ́ \varsigma$ word personifieer om 'n hele aantal funksies in die innerlike geregshof te

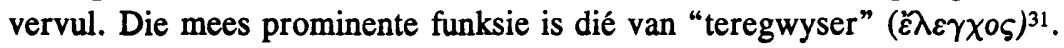
Deur die $\sigma v \nu \varepsilon \imath \delta o ́ \varsigma$ konseptueel aan die bestaande konsep van die innerlike $\tilde{\varepsilon} \lambda \varepsilon \gamma \chi \circ \varsigma_{S}$ te koppel ${ }^{32}$, verruim Philo die gewetenskonsep aansienlik en bevry dit in die proses van die uitsluitlik negatiewe funksie wat dit in die vroeër Griekse literatuur gehad het.

\section{EIENSKAPPE VAN PAULUS SE GEWETENSKONSEP}

\section{1 'n Eie stempel op 'n ontwikkelende konsep}

As Paulus se gebruik van $\sigma u \nu \varepsilon i \delta \eta \sigma \iota \varsigma$ vergelyk word met die oúvoı $\delta \alpha$ woordgroep in ouer en kontemporêre literatuur, blyk die Joods-Hellenistiese dualiteit in sy mondering baie duidelik. Aspekte van die tipies Griekse konseptuele raamwerk is onteenseglik teenwoordig, maar Paulus gee 
telkens 'n on-Griekse wending daaraan. Die gevolg is dat sy konsep nie meer netjies op 'n Griekse rooster pas nie.

Paulus se vrye manier van omgang met die woord kan aan twee faktore toegeskryf word: sy Joodse agtergrond, en die feit dat die gewetenskonsep in sy tyd nog vaag omlyn was. Om een opvallende voor-

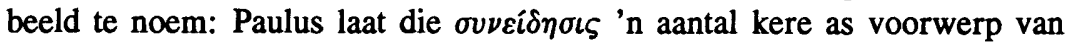
die werkwoord optree, en wel as 'n lydende voorwerp: in 1 Korintiërs 8:7

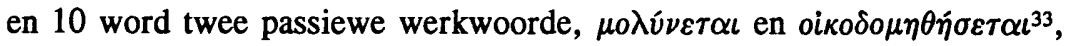

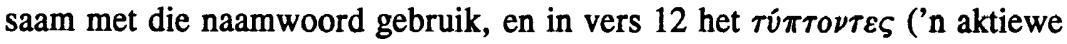
partisipium) $\sigma u \nu \varepsilon i \delta \eta \sigma \iota \varsigma$ as voorwerp. In vroeër en selfs in later literatuur is dit egter gewoonlik die $\sigma u \nu \varepsilon i \delta \sigma \iota \varsigma$ wat aktief optree deur straf uit te deel, voort te dryf, te pynig, kwel, aan te kla en te ontstel ${ }^{34}$. Hoewel die passiewe en aktiewe rolle nie onversoenbaar is nie ('n "besoedelde" of 'n "gewonde" gewete kan die subjek daarvan ook "voortdryf", "ontstel" "pynig" of "aankla"), is dit duidelik dat Paulus in die geval van 1 Korintiërs 8-11:1 die konsep aan sy tekstuele strategie onderwerp. Hy wil empatie en 'n verantwoordelikheidsin by die Korintiese sterkes jeens hul

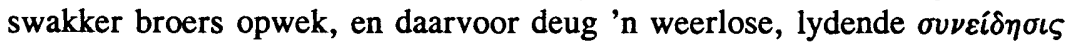
veel beter! Wanneer tradisionele topoi dus by Paulus se gebruik van

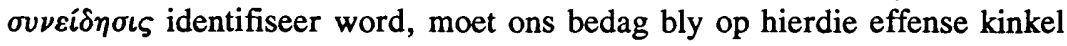
wat hy aan die tradisionele inhoud gee.

\subsection{Gewete as innerlike monitor}

Die kernfunksie van Paulus se $\sigma v \nu \varepsilon i \delta \eta \sigma \iota \varsigma$ is dat dit as 'n innerlike monitor

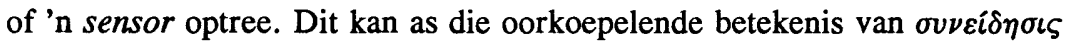
by Paulus beskou word, sodat ons wel kan sê dat Paulus die woord "einheitlich" gebruik.

Die funksie van innerlike monitor is 'n nuwe aspek van die woord wat deur Paulus ontgin word. Ons moet in gedagte hou dat die verskynsel genoem $\sigma v \nu \varepsilon i \delta \eta \sigma \iota \varsigma$ of $\sigma v \nu \varepsilon \iota \delta o ́ \varsigma$ (soos by Philo, Josephus en Plutarchus)

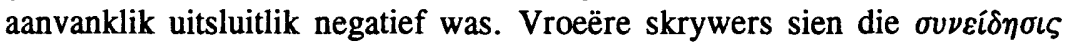
nie as 'n permanente onderdeel van die menslike psige nie: dit was iets wat eers ontstaan het nadat die persoon bewustelik een of ander oortreding begaan het, die skuldige besef van jou eie misstap waarmee jy teen wil en

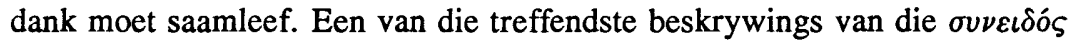
vind ons by die eerste eeuse moralistiese filosoof Plutarchus. Hy vergelyk iemand wat 'n onbesonne daad gepleeg het met 'n vis wat 'n stuk aas insluk, net om te vind dat daar 'n hoek binne-in die aas is wat hom nou in sy binneste pynig en hom op 'n dolle jaagtog deur die see voortdryf ${ }^{35}$. Die hoek binne-in die aas is die $\sigma v \nu \varepsilon \iota \delta o ́ s$, oftewel die "skuldige gewete". 


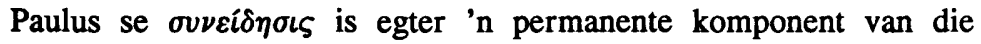
menslike siel. Die permanensie het 'n belangrike invloed op die definisie van "gewete" uitgeoefen: die gewete is nie meer net 'n pynigende bedreiging nie, maar 'n neutrale entiteit wat positiewe én negatiewe "seine" kan registreer en so "rein" of "onrein" kan word. In 1 Korintiërs 8:7 veronderstel Paulus dat 'n "rein" $\sigma \nu \nu \varepsilon i \delta \eta \sigma \iota \varsigma$ "onrein" kan word as dit "besoe-

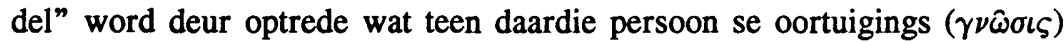
indruis. Die gewete het dus 'n wesenlik neutrale karakter aangeneem wat positief of negatief kan reageer op die morele gehalte van gedrag.

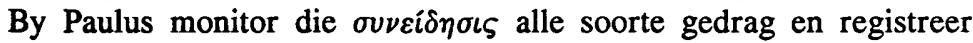
enige afwykings van die etiese standaard. Die monitor is nie beperk tot die beoordeling van uiterlike gedrag nie: ook die "verborgenhede van die hart", intensie en die gesindheid waarmee iets gedoen word, word beoor-

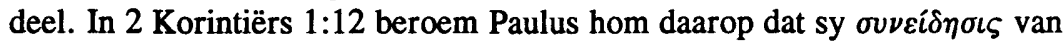
sy eie integriteit en ongeveinsdheid getuig. Dit bring ons by 'n volgende prominente aspek van Paulus se gewetenskonsep: die funksie daarvan as getuie.

\subsection{Getuie van die innerlike geregshof}

Reeds vanaf die vyfde eeu vC word die $\sigma u ́ v o \iota \delta \alpha$ woordgroep in forensiese kontekste aangetref. Veral die nie-refleksiewe verbale frases kom voor waar daar verwys word na medepligtigheid in komplotte en sameswerings (ons "weet met mekaar" wat ons beplan het) en na getuienis wat teen iemand gelewer word (ek "weet met hom" wat hy gedoen het en kan dus teen hom getuig) ${ }^{36}$. Mettertyd het 'n "wete met myself" ook 'n forensiese rol begin speel: sekere gedragstekens het daarop gedui dat iemand wat teregstaan ook skuldig voel, dat hy met ander woorde "met homself weet" dat hy oortree het ${ }^{37}$. By Philo van Alexandrië vind ons egter vir die eerste keer dat die oúvol $\delta \alpha$ woordgroep saamgesnoer word met die kragtige metafoor van 'n innerlike geregshof ${ }^{38}$. Philo se $\sigma v \nu \varepsilon \iota \delta o ́ \varsigma$ vervul 'n verskeidenheid funksies in die innerlike geregshof. Soms is dit regter ( $\delta \iota \alpha \sigma \tau \eta \dot{\eta} \varsigma ;$ Deus

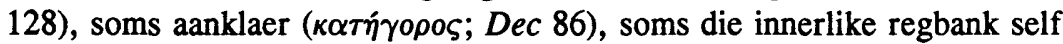

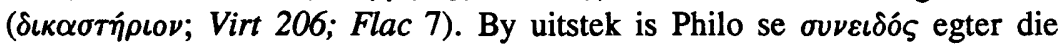
"teregwyser" ( $(\bar{\varepsilon} \varepsilon \gamma \chi \circ \varsigma$ ) wat aan die een kant straf, berispe en pynig, maar aan die positiewe kant ook onderrig en vermaan (Dec 86 e v; Opif 128).

Forensiese terminologie kom nie so uitgebreid in die kontekstuele

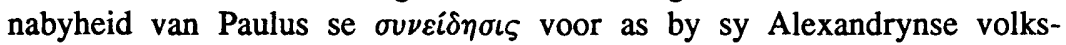
genoot se $\sigma \nu \nu \varepsilon\llcorner\delta o ́ \varsigma$ nie. Nogtans is dit sterk aanwesig. Daarvan spreek die werkwoorde $\kappa \rho i ́ \omega \omega / \dot{\alpha} \nu \alpha \kappa \rho i \nu \omega$ en $\delta \iota \kappa \alpha \iota \omega^{\omega} \omega$ saam met die verwysing na 'n menslike hof ( $\left.\dot{\alpha} \nu \theta \rho \omega \pi i \nu \eta \dot{\eta} \mu \varepsilon^{\prime} \rho \alpha\right)$ in 1 Korintiërs $4: 3$, en die getuienis 


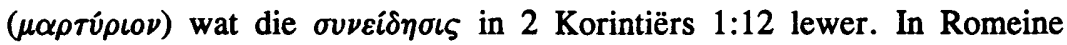
13:1-7 impliseer Paulus dat die innerlike geregshof 'n supplementêre rol speel naas die uiterlike gesag van die owerhede: die owerhede is deur God aangestel as aardse instandhouers van "die goeie" (rò $\dot{\alpha} \gamma \alpha \theta \dot{\nu} \nu$ ); wie oortree sal 'n oordeel $(\kappa \rho i \mu \alpha)$ ontvang, hetsy by wyse van die owerhede se "wraak" $(\delta \rho \gamma \eta)$ of by wyse van die innerlike $\sigma u \nu \varepsilon i \delta \eta \sigma \iota s$ wat reageer wanneer daar van die maatstaf van "die goeie" afgewyk word. Paulus beveel by die Romeinse gelowiges aan om hulle aan die owerhede te onderwerp, gedagtig aan beide innerlike en uiterlike wyses waarop "die goeie" in stand gehou word.

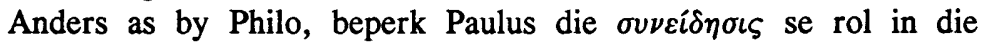
innerlike geregshof tot dié van getuie (2 Kor 1:12; Rom 2:15; 9:1). Dié rol

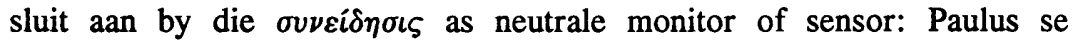

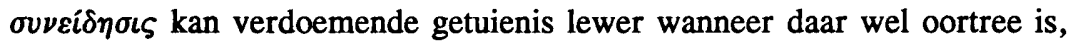
maar die getuienis daarvan kan ook as aanbeveling dien of selfs apploudeer as die persoon se gedrag onbesproke is (2 Kor 1:12). In Romeine 2:15

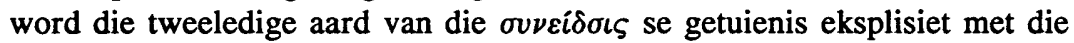
twee werkwoorde $\kappa \alpha \tau \eta \gamma o \rho \varepsilon \dot{\varepsilon} \omega$ en $\dot{\alpha} \pi \circ \lambda o \gamma \varepsilon \dot{\varepsilon} \omega$ tot uitdrukking gebring ${ }^{39}$. Soos

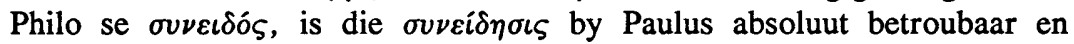

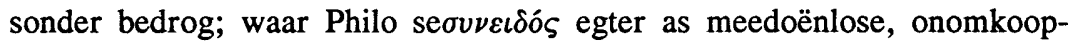

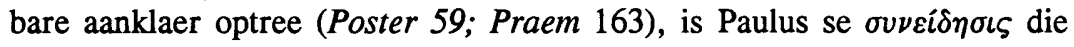
absoluut onpartydige getuie.

Waaroor strek die jurisdiksie van die gewete as getuie? Die innerlike geregshof oordeel oor menslike doen en late. Dit oordeel veral oor kwaliteite wat nie direk uiterlik sigbaar is nie, die "bedoelinge van die hart"

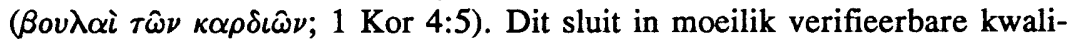
teite soos opregtheid, eerlikheid, goeie bedoelings en lojaliteit, of - die teenoorgestelde daarvan - "verborge dinge van skandelikheid" (2 Kor 4:2), onsuiwere motiewe en valsheid. As monitor en getuie van die verborgen-

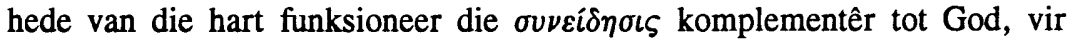

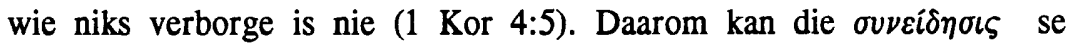
getuienis ook saam met Christus en die Heilige Gees as waarborge dien dat die waarheid gepraat word (Rom 9:1).

\subsection{Verteenwoordiger van waarheid}

Dit is ' $n$ ou en eerbiedwaardige motief in die Israelitiese en Joodse gedagtegoed dat 'n mens se gedagtes, oorweginge en gesindhede nie vir God verborge is nie ${ }^{40}$. Die vraag is egter, waarvandaan kry die $\sigma u \nu \varepsilon i \delta \eta \sigma \iota \varsigma$ hierdie vermoë om - soos God - die menslike innerlike te monitor en te beoordeel? Oortree Paulus se gewetenskonsep nie op goddelike terrein nie? 
Of meen hy dalk dat die gewete iets goddelik is en dieselfde funksie as die Heilige Gees vervul? Wat laasgenoemde vraag betref, is geleerdes sedert

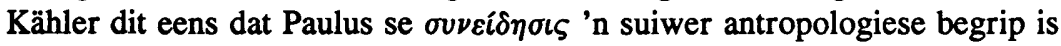
en nie die vox dei, God se stem in die hart van die mens nie ${ }^{41}$. Ons moet dus probeer vasstel hoe hierdie suiwer menslike gegewe wat Paulus die

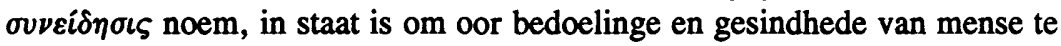

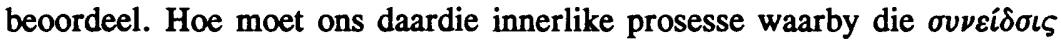
betrokke is, verstaan? Die antwoord hierop kan gevind word in 'n kombinasie van die geskiedenis van die $\sigma u ́ v o \iota \delta \alpha$ woordgroep en die unieke wyse

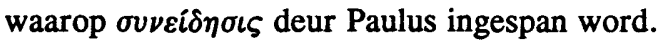

Die vermoë om as betroubare getuie in etiese kwessies op te tree, veronderstel kennis van (i) die waardesisteem waarin dit wat as reg en goed geld, vervat is, en van (ii) waar daar van die waardesisteem afgewyk is, al is dit beperk tot die "bedoelinge van die hart". Paulus reflekteer nêrens in sy briewe direk oor hierdie problematiek nie. Die samehang van hierdie aspekte van die gewete moet by wyse van konjekture gekonstrueer word. Gelukkig dui die aanwesigheid van bepaalde terminologie daarop dat Paulus met die gebruik van die woord binne tradisionele bane beweeg.

Ons begin by laasgenoemde stel informasie: hoe registreer die

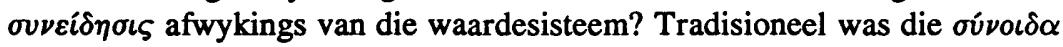
woordgroep altyd betrokke by 'n psigiese toestand van innerlike disharmonie. Die persoon word bewus van 'n konflik tussen wat hy gedoen of beplan het, en wat hy weet hy eerder moes doen. Ons vind dan ook die werkwoord $\tau \alpha \rho \alpha ́ \sigma \sigma \varepsilon \iota \nu$ (om te ontstel, ontstig, verontrus, verwar) as een van die prominente woorde in assosiasie met die oúvol $\delta \alpha$ woordgroep ${ }^{42}$. Die innerlike wanorde, wat ook as 'n gebrek aan integriteit ${ }^{43}$ beskryf kan word, gaan gepaard met vrees, pyn, onsekerheid, en ander derglike simptome van 'n geestelike krankheid ( ó $\left.\sigma o \varsigma \psi v \chi \varepsilon^{\varepsilon} \omega \varsigma\right)^{44}$. In Klassieke Griekeland is hierdie soort simptome onder andere toegeskryf aan daardie "wete met jouself" wat spontaan, noodwendig en sonder uitsondering op 'n oortreding volg45. Versteurings van innerlike harmonie is voorts toegeskryf aan diskrepansies tussen woorde en dade, of tussen gedagtes, woorde en dade, soos wanneer 'n persoon met onegte bedoelings en geveinsd optree, vleitaal gebruik of huigel ${ }^{46}$. Ook in hierdie gevalle registreer die

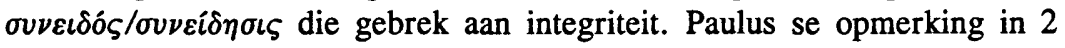
Korintiërs 1:12 moet ongetwyfeld binne hierdie konseptuele raamwerk gelees word.

Paulus se gewete kan dus getuig oor 'n persoon se integriteit omdat dit so sensitief is vir enige intrapsigiese versteurings of diskrepansies

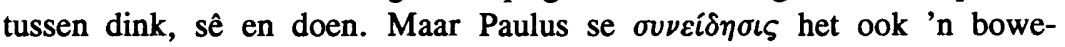


persoonlike funksie, naamlik om gedrag te meet aan die eise van "die waarheid" (Rom 1:18, 25; 2:2, 8)47 of "die goeie" (Rom 13:3-5). Dit bring ons by die tweede stel informasie waaroor die gewete skynbaar beskik: kennis van die geldende waardes.

Weer eens moet daarop gewys word dat Paulus nie blyke gee van refleksie oor kennislerige kwessies nie. 'n Analise van Paulus se gebruik van rasionele terminologie toon egter dat die apostel nie die optimisme van sy filosofiese tydgenote deel ten opsigte van menslike kenvermoë nie. In 1 Kor 2-4 betoog Paulus vir die beperking van menslike kenvermoë: mens-

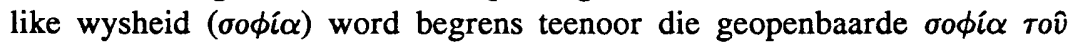
$\theta \varepsilon o \hat{v}$, vergestalt in die gekruisigde Christus. In 1 Korintiërs 8:1-13 blyk dieselfde opvatting oor die beperkinge van $\gamma \nu \hat{\omega} \sigma \iota \varsigma$ uit Paulus se hantering van die offervleis-kwessie (kyk 8:1; 7). Maar uit beide gedeeltes blyk terselfdertyd ook die noue verwantskap tussen $\gamma \nu \hat{\omega} \sigma \iota \varsigma$ en $\sigma \nu \nu \varepsilon i \delta \eta \sigma \iota \varsigma:$ ook al weet Paulus van niks met homself nie, is hy nie daarom verontskuldig nie. Die finale oordeel kom God alleen toe (1 Kor 4:4); iemand wat "swak" is as gevolg van sy gebrekkige kennis, het vanselfsprekend ook 'n

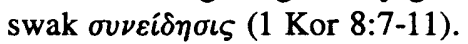

Die verbintenis tussen gewete en kennis by Paulus toon ooreenkomste met die wyse waarop die oúvol $\alpha$ woordgroep tydens die Hellenistiese tydvak betrek is by epistemologiese terminologie en die vraag na die waarheid ${ }^{48}$. Die hele kwessie rondom 'n vaste grondslag vir etiese reëls gryp terug na die vyfde eeuse debat oor die verhouding tussen $\phi v ́ \sigma \varsigma$ (natuur, hoe dinge "van nature is") en vó $\mu \circ \varsigma$ (menslike konvensies, wette, en so meer). Die mees radikale Sofistiese standpunt was dat slegs $\phi \dot{v} \sigma \iota \varsigma$ op waarheid aanspraak kan maak, en dat alle menslike konvensie berus op verdraaiings van die waarheid49. Die Hellenistiese (veral die Stoïsynse) filosowe het gepoog om $\phi u ́ \sigma \iota \varsigma$ en vó $\mu$ os met mekaar te versoen. Die

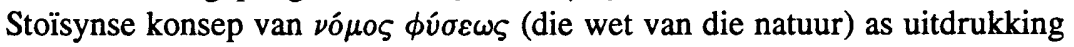
van die kosmiese $\lambda o ́ \gamma o s$, spreek van hulle strewe om 'n lewenswyse volgens die natuur te formuleer ${ }^{50}$. Die gehelleniseerde Jodedom kon gemaklik hierby aansluit, en kon boonop 'n tradisioneel Joodse stempel daarop plaas: God is beide die Skepper en Onderhouer van die kosmos; dieselfde God het sy wil aan Moses in die vorm van wette geopenbaar ${ }^{51}$.

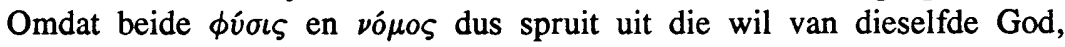
bestaan daar volledige korrespondensie tussen natuur, die Mosaïese wette en die waarheid.

Vir Paulus verwys die konsep waarheid ( $\dot{\alpha} \lambda \dot{\eta} \theta \varepsilon \iota \alpha)$ na (i) die korrekte wêreldbeskouing (nl dat God alles geskep het en dit onderhou) wat bepaalde kennis veronderstel, en (ii) die eties-religieuse eis wat dit stel (nl dat die 
mens Hom daarvoor moet eer). Die waarheid behels "dinge soos wat hulle is" sowel as die korrekte menslike respons daarop. Aan die een kant is $\dot{\alpha} \lambda \dot{\eta} \theta \varepsilon \iota \alpha$ die teenoorgestelde van onreg ( $\dot{\alpha} \delta\llcorner\kappa i \alpha)$ en goddeloosheid

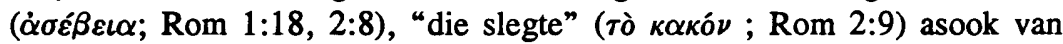
dinge wat uit skaamte weggesteek word en allerlei vorme van valsheid (2 Kor 4:2). Aan die ander kant korrespondeer dit met die voorskrifte van

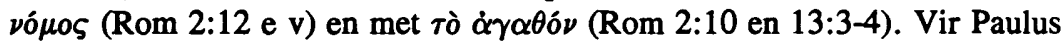
het die waarheid altyd 'n sterk eties-appellerende dimensie.

Hoe Paulus presies die verband tussen die gewete en die waarheid sou definieer, is nie duidelik nie. Ons kan slegs aanvaar dat Paulus ook,

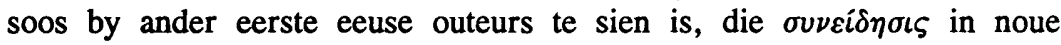
verwantskap met ander rasionele terminologie soos die verstand/denke

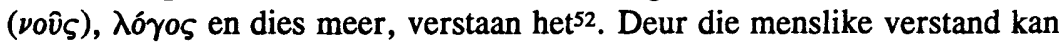
toegang verkry word tot die waarheid, wat bestaan uit die korrekte kennis. Die mees voor-die-handliggende bron van korrekte kennis is natuurlik die wet; die heidene wat die wet nie het nie, maar wat deur hulle gedrag toon dat die wet se eise in hulle harte geskrywe staan (Rom 2:15), het egter ook toegang tot die waarheid.

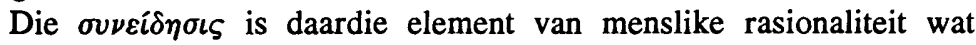
spanninge registreer tussen ' $n$ indiwidu se insae in die waarheid en sy/haar optrede (wat gedagtes, bedoelinge, woorde en dade insluit). Dit beteken egter nie dat alle mense ewe veel van die waarheid beet het nie: soos wat die geval van die "swakkes" in Korinte getuig, is daar graadverskille in mense se "kennis", en die indiwiduele $\sigma v \nu \varepsilon i \delta \eta \sigma \iota \varsigma$ reageer op grond van die graad van kennis tot beskikking van daardie indiwidu.

\subsection{Beoordelaar van ander}

Paulus se siening dat iemand se gewete 'n oordeel kan vel oor die gesindhede en optrede van 'n ander persoon, het wel raakpunte met die konseptuele raamwerk van die oúvoเ $\alpha$ woordgroep. Tog is dit 'n eg Pauliniese wending wat in die later gebruik van die woord weinig of geen navolging gevind het nie.

Hoe sluit hierdie aspek by die tradisionele konseptuele raamwerk aan? Reeds in vyfde eeuse literatuur is ' $n$ "wete met jouself" of ' $n$ "wete met iemand anders" beskryf in terme van die invloed wat dit op 'n persoon se interaksie met ander persone het. Wanneer iemand 'n skuldige wete deel, is dit primêr in verband gebring met 'n verknegtende geïnhibeerdheid: daardie persoon boet in aan sy vryheid teenoor sy gelykes; hy sukkel om homself te handhaaf, kan ander nie in die oë kyk nie, kan nie sy vryheid van spraak beoefen nie en probeer om interaksie te vermy ${ }^{53}$. By 
Philo word hierdie geïnhibeerdheid eksplisiet geassosieer met die

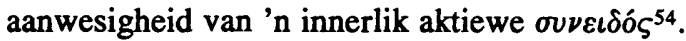

Die interessante verskynsel is dat Paulus hierdie assosiasie van

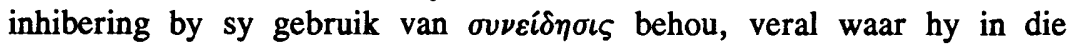
Tweede Korintebrief sy apostelskap verdedig. Hy bring dit egter in

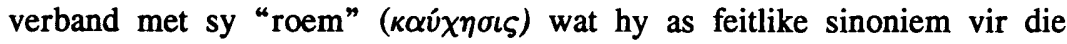
konsep van "vrymoedigheid" ( $\pi \alpha \rho \rho \eta \sigma i \alpha)$ gebruik ${ }^{55}$. Die inhoud of rede vir

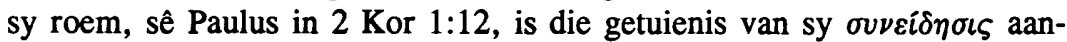
gaande sy eie integriteit en ongeveinsdheid. Ons kan dus duidelik sien dat

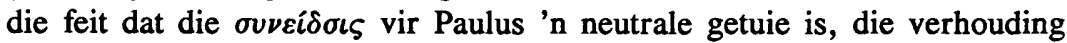
tussen die woord en die $\pi \alpha \rho \rho \eta \sigma i \alpha$-topos dramaties beïnvloed het. Dit is nie

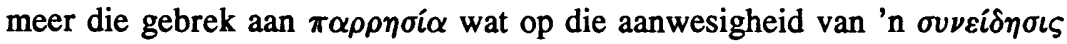

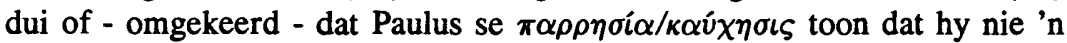

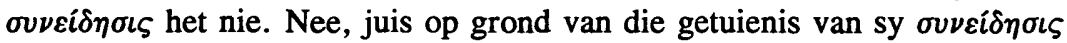
kan hy met vrymoedigheid optree en roem.

In die ander twee gevalle waarin die woord ovveínoıs in die Tweede Korintebrief voorkom (4:1-6; 5:11-15), speel dieselfde assosiasies 'n rol, maar die rolle word gewysig. Hier stel Paulus sy optrede oop vir

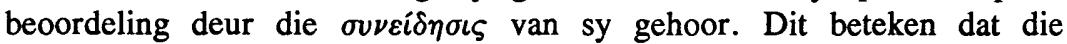
$\sigma v \nu \varepsilon i \delta \eta \sigma \iota \varsigma$ nog steeds as spesialis-getuie van innerlike integriteit funksioneer, maar nou die integriteit van 'n ander persoon. Aangesien 'n ander persoon se intra-psigiese prosesse egter ontoeganklik is, hoe is dit vir die Korintiërs se gewete moontlik om daaroor te oordeel? Daar is twee moontlikhede: of die Korintiërs word opgeroep om te oordeel of daar diskrepansie is tussen wat Paulus verkondig en hoe hy self optree, òf die Korintiërs kan op grond van Paulus se $\pi \alpha \rho \rho \eta \sigma i \alpha / \kappa \alpha \dot{\chi} \chi \eta \sigma \iota \varsigma$ oordeel dat hy nie innerlik aangekla staan nie. In 2 Korintiërs 4 blyk beide moontlikhede teenwoordig te wees: Paulus toon vrymoedigheid deur homself bloot te stel, sodat sy suiwer motiewe deur sy "blootstelling” duidelik kan blyk:

Daarom, aangesien ons hierdie bediening het soos wat ons begenadig is, word ons nie moedeloos nie, maar ons het die verborge dinge van skandelikheid afgelê sodat ons nòg oneerlik lewe nòg die woord van God vervals, maar in die openbaarmaking van die waarheid stel ons onsself ten

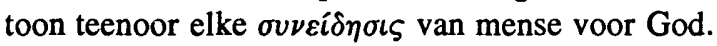

\section{RAAKPUNTE MET ANDER TEOLOGIESE KWESSIES BY PAULUS}

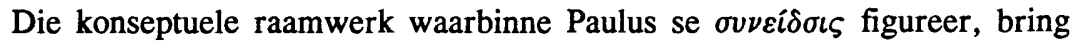
dit noodwendig in aanraking met 'n hele verskeidenheid teologiese en etiese motiewe. Ek raak kortliks die mees prominente daarvan aan. 


\subsection{Gewete en etiese outonomiteit?}

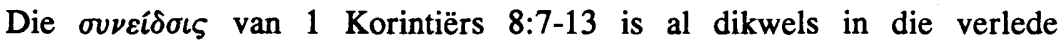
verkeerdelik gebruik om die outonomiteit van die gewete by Paulus te bewys. Hiervolgens is die indiwidu verplig om sy eie gewete te gehoorsaam: selfs al is dit 'n "fouterende gewete", bly die aansprake daarvan steeds geldig. Kähler meen dat Paulus aan elke indiwidu die reg toeken om te besluit oor die norme wat vir homself geldig is. Volgens Kähler bring dit enersyds mee dat die indiwidu verantwoordelik gehou word om volgens daardie norme te lewe; andersyds dat selfs 'n fouterende gewete nie negeer mag word ten gunste van 'n eksterne outoriteit nie, omdat dit tot die vernietiging van die indiwidu sal lei ${ }^{56}$.

Kähler benader die kwessie egter vanuit 'n verkeerde hoek, sodat dit daaruit lyk asof (i) Paulus 'n voorstander is van etiese indiwidualisme wat (ii) deur die indiwiduele gewete voorgeskryf word en (iii) van die indiwidu vereis om gehoorsaam te word. Morele verpligting om die gewetenseis te gehoorsaam, veronderstel dat daar sprake is van 'n morele keuse deur die indiwidu om gehoorsaam te wees of nie. Daarteenoor is die korrekte invalshoek dat daar 'n noodwendige, spontane proses veronderstel word

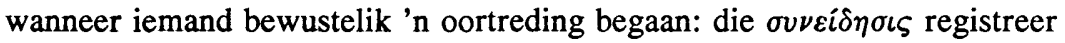
die oortreding spontaan, sodat daar onvermydelik 'n innerlike proses aan die gang gesit word wat pynlike gevolge vir daardie persoon het. Die

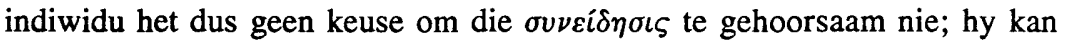

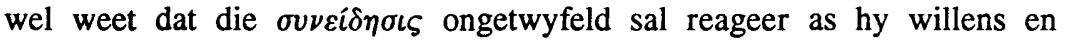
wetens oortree.

Wat wel vir Paulus relatief tot die indiwidu is, is kennis van wat reg

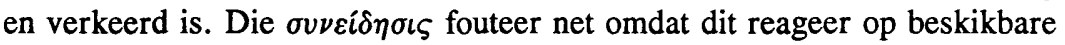
kennis, wat in sommige gevalle foutief of gebrekkig kan wees. Gebrekkige $\gamma \nu \hat{\omega} \sigma \iota \varsigma$ lei tot 'n $\sigma \nu \nu \varepsilon i \delta \eta \sigma \iota \varsigma$ wat - vanuit die perspektief van meerdere $\gamma \nu \omega \sigma \sigma \varsigma$ - in werking tree waar dit nie nodig is nie. As Paulus die feit van relatiewe kennis erken, beteken dit nie dat hy aan die Korintiese swakkes die reg toeken om oor hulle eie norme te besluit en elke indiwidu dus eties outonoom verklaar nie: hy dra bloot hulle welwese op die hart en wil voorkom dat hulle in 'n onhoudbare posisie geplaas word. Hy keer nie hulle swakheid positief goed nie, maar wil aan hulle ruimte bied om in kennis en geloof te groei ${ }^{57}$.

Dit is dus belangrik om die noodwendige verband tussen gedrag en

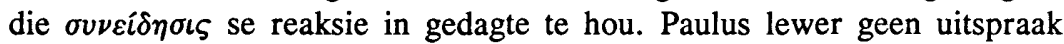
oor die geldigheid al dan nie van die swak of fouterende $\sigma v \nu \varepsilon i \delta \eta \sigma \varsigma$ nie: hy aanvaar bloot dat dit deur die situasie in werking gestel sal word, met die gewone negatiewe gevolge. Dit is hierdie onontwykbare proses, met die 
onaangename en nadelige gevolge wat dit vir die swakkes inhou, wat Paulus veronderstel en wat as uitgangspunt van sy argument dien ${ }^{58}$.

\subsection{Gewete en die eskatologiese oordeel}

Dit is onvermydelik dat die innerlike geregshof-topos in aanraking moet kom met Paulus se sterk eskatologiese perspektief, veral met die komende finale oordeel. Hoewel Romeine 13 en selfs 1 Korintiërs 8-10 die gewete by ' $n$ vorm van immanente vergelding betrek, is dit duidelik dat Paulus die gewete ondergeskik stel aan die finale oordeel. Die innerlike geregshof is onvolmaak omdat dit steeds op menslike oordeel en kennis berus; slegs die

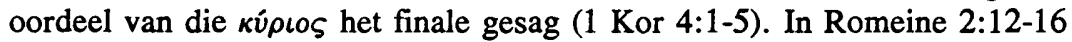
is die spanning tussen die innerlike, immanente oordeel en die eskatologiese oordeel te sien in vers 16 se onverwagte swaai van die teenwoordige

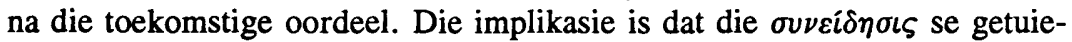
nis ook tydens die finale oordeel 'n rol sal speel. Vir Paulus het alles wat in die hede plaasvind eskatologiese implikasies.

\subsection{Gewete en kennis van metafisiese absolutes}

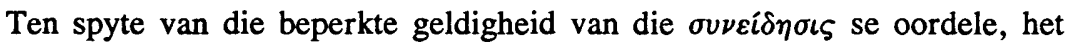
Paulus nogtans hoë waardering vir die getuienis daarvan, veral waar die Tora nie beskikbaar is nie (Rom 2:12-16). Die blote feit dat mense 'n

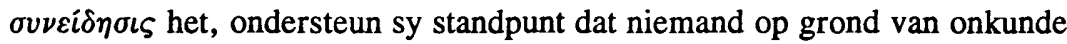

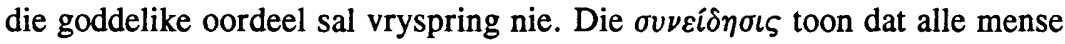
minstens 'n mate van begrip het van God en van die waarheid. Daarom is

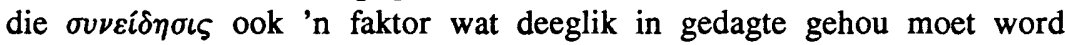
wanneer iemand dit sou oorweeg om teen die owerhede in opstand te kom (Rom 13:1-6). Opstand teen die owerhede is per definisie die verwerping van "die goeie" wat die owerhede op bevel van God in stand moet hou. As

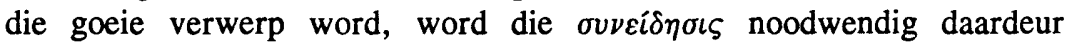
geaffekteer of geaktiveer.

\subsection{Gewete en apostoliese integriteit}

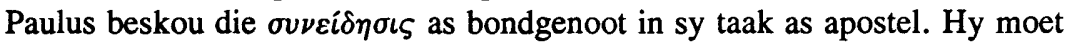
nie net die waarheid van die evangelie aan mense meedeel nie: hy moet hulle ook oortuig dat hyself as apostel 'n betroubare makelaar van die waarheid is en dat hy slegs sy hoorders se belange op die hart dra. Daarom

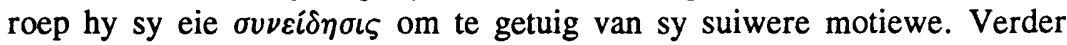
stel hy ook homself, sy lewenswyse en bedieningswyse bloot aan die

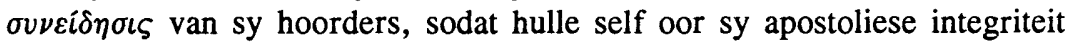
kan oordeel. 


\subsection{Gewete en onderlinge sorg}

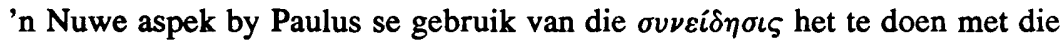
deurbreking van die indiwidualiserende tendense in die Hellenistiese etiek.

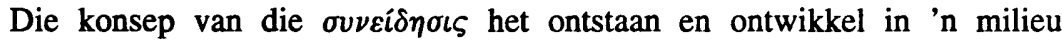
waarin daar gestreef is na die ideale innerlike toestand van selfbeheersing, kalmte en harmonie ${ }^{59}$. Slegs om dié rede is die goeie en deug $(\dot{\alpha} \rho \varepsilon \tau \dot{\eta})$ nagestreef, nie ter wille van die welwese van ander nie. Vir die Stoïsyne was enigiets gevaarlik wat hulle innerlike harmonie kon versteur (soos die skuldige besef van 'n oortreding). Die Stoïsynse wyse wat hierdie ideaal vervolmaak, is al tereg beskryf as "a monster, passionless, pitiless, perfect; he would do good, but without feelings for others, for his calm must remain unruffled..."60.

In 1 Korintiërs 8-10 span Paulus egter die konsep op 'n unieke wyse in om sorg vir en verantwoordelikheid teenoor medegelowiges tot die hoogste etiese vereiste te verhef: as daar dan klem gelê word op die innerlike welsyn van die indiwidu, moet die gelowiges vir mekaar se

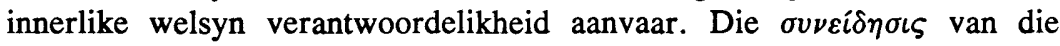
swak broer, kwesbaar juis as gevolg van sy swakheid, kan skade aangedoen word. Situasies wat daartoe aanleiding kan gee, moet ten alle koste

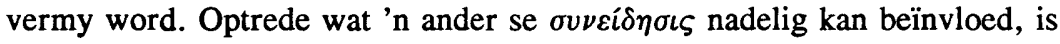
sonde. My vryheid van optrede ( $\dot{\varepsilon} \xi o v \sigma i \alpha)$ word begrens deur die eis dat daar op die ander se $\sigma u \nu \varepsilon i \delta \eta \sigma \iota \varsigma$ ag geslaan moet word: nie net omdat ek vir die ander persoon lief is en weet dat Christus ook vir daardie persoon gesterf het nie, maar ook omdat die oordeel wat die ander persoon se

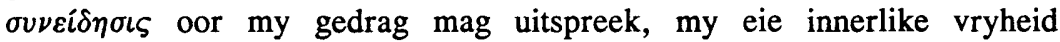
( $\dot{\varepsilon} \lambda \varepsilon v \theta \varepsilon \rho i \alpha)$ aan bande kan lê. Vir Paulus word die indiwidu dus onteenseglik as ondergeskik aan die belange van die gemeenskap van gelowiges geplaas.

\subsection{Gewete en die soewereine God}

Die wyse waarop die $\sigma \dot{v} v o \iota \delta$-woordgroep in 1 Korintiërs $4: 4$ gebruik word, laat iets blyk van 'n wesenskenmerk van Paulus se teologie. Die teenstelling tussen menslike en Goddelike wysheid dui op 'n diepgaande verskil in Godsbeskouing tussen Paulus en sy Hellenistiese omgewing soos dit in - onder andere - die werke van Philo van Alexandrië na vore tree. Beide Paulus en Philo het 'n transendente Godsbeskouing, maar Philo se God vergestalt in vele opsigte eerder 'n filosofiese ideaal. Vir Philo is die hoogste in die mens - sy rasionaliteit - 'n wesenskenmerk van God self. Vir Paulus daarenteen, is God soewerein, los van rasionele en filosofiese dwang: God kan die wysheid van mense op die kop keer. Philo se God is 
noodwendig toegankliker is vir die filosofies geskooldes, dit wil sê, vir die wysheidselite ${ }^{61}$. Vir Paulus kan God 'n bespotting maak van die wysheid van hierdie wêreld en van die maghebbers van hierdie wêreld (1 Kor 2:6 e v) deur in vryheid sy keuse van volgelinge te maak uit dié wat nie aan gewone standaarde ( $\kappa \alpha \tau \grave{\alpha} \sigma \alpha ́ \rho \kappa \alpha)$ gemeet, baie wys of magtig of adellik is nie (1 Kor 1:26 e v).

Dit beteken egter nie dat Paulus ook vir God losmaak van wat as eties goed en reg geld nie. God bly die oorsprong van die absolute goeie en die waarheid, van die maatstawwe waarop die $\sigma v \nu \varepsilon i \delta \eta \sigma \iota s$ reageer in die mate waarin iemand oor akkurate kennis daarvan beskik. Soos vir die $\sigma v \nu \varepsilon i ́ \delta \eta \sigma \iota s$, lê die menslike innerlike, die bedoelinge van die hart, oop en

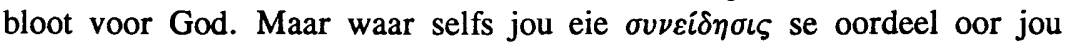
diepste innerlike motiewe relatief bly, dra God se oordeel daaroor - omdat Hy alleen absolute kennis het - finale gesag (1 Kor 4:4-5).

\section{NOTAS:}

1 Artikel gebaseer op navorsing wat die skrywer gedoen het vir DD-proefskrif in die Departement Nuwe Testament (Teologie B) aan die Universiteit van Pretoria.

2 Kyk die navorsingsoorsigte van J Stelzenberger, Syneidesis im Neuen Testament, Paderborn 1961, 11-27; R Jewett, Paul's anthropological terms: A study of their use in conflict settings. Leiden 1971, 402-421; H-J Eckstein, Der Begriff Syneidesis bei Paulus: Eine neutestamentlich-exegetische Untersuchung zum Gewissensbegrif, Tübingen 1983, 13-33.

3 Veral die gebruik van die terme by Philo en Seneca blyk van deurslaggewende belang te gewees het; vergelyk A Pelletier, "Deux expressions de la notion de conscience dans le judaïsme hellénistique et le christianisme naissant", $R E G 80$ (1967), 369-370.

4 Die gewilde Middeleeuse konsep sunteresis of sunderesis het ontstaan as gevolg

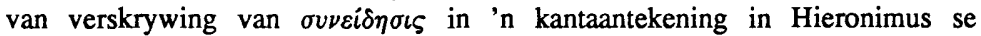
Esegiëlkommentaar tot $\sigma v \nu \tau \dot{\rho} \rho \eta \sigma \varsigma$ ("bewaring”). Thomas Aquinas bespreek die twee konsepte conscientia en sunderesis in twee opeenvolgende hoofstukke van sy Quaest de ver 16 en 17.

5 Vir bondige besprekings en literatuurlyste van die Lutherse en reformatoriese gewetenskonsepte, kyk E Wolff, s v "Gewissen". RGG 1958, 1553-1554; F Krüger, s v "Gewissen. III. Mittelalter und Reformationszeit", TRE, 1984, 219225.

6 Kyk J-G Blühdorn, s v "Gewissen. I. Philosophisch”, TRE, 1984, 202-210.

7 M Kähler, Das Gewissen: Etische Untersuchung. Die Entwicklung seiner Namen und seines Begriffes. Erste, geschichtlicher Teil: Geschichtliche Untersuchung zur Lehre von der Begründung der sittlichen Erkenntnis. Erste Hälfte: Altertum un Neues Testament. Darmstadt [1878] 1967; s v "Gewissen", RE, 1899. Vir 'n oorsig oor ander negentiende eeuse bydraes, kyk Stelzenberger, $a w, 15-20$. 
8 Die gewete word gewoonlik in verband gebring met morele keuses aan die een kant en die beoordeling van morele gedrag aan die ander kant. Eersgenoemde word - op grond van 'n onderskeiding gemaak in sewentiende eeuse Spaanse skolastiek - die antisiperende werking van die gewete of die conscientia antecedens genoem en verwys na die vermanende, waarskuwende of rigtinggewende krag wat 'n rol speel voor of terwyl 'n morele keuse gemaak word. Laasgenoemde word genoem die retrospektiewe werking of die conscientia consequens, en verwys na die psigiese aktiwiteit spruitend uit optrede wat reeds begaan is: die optrede word terugskouend beoordeel en goedgekeur of afgekeur. In omgangstaal verwys ons dan na 'n geruste, goeie, of rein gewete as die oordeel goedkeurend is, en na 'n onrustige, slegte, skuldige, beswaarde of gekwelde gewete indien die oordeel negatief is.

9 Literatuurlyste by Wolff, $a w, 1556$; $M$ Wolter, s v "Gewissen. II Neues Testament", TRE 1984, 218.

10 C A Pierce, Conscience in the New Testament: A study of syneidesis in the New Testament; in the light of its sources, and with particular reference to St. Paul; with some observations regarding its pastoral relevance today. London 1955; Stelzenberger, $a w$; Eckstein, $a w$.

11 Onder andere J Gründel (Hrsg) Das Gewissen: Subjektive Willkür oder oberste

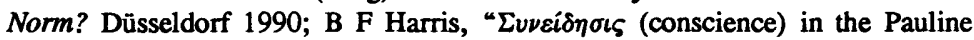
writings”, WThJ 24 (1962), 173-186; P Hilsberg, “Das Gewissen im Neuen Testament: Über die Anwendung und Nichtanwendung des Wortes Gewissen im Neuen Testament", ThV 9 (1977), 145-160; R Horsley, "Consciousness and freedom among the Corinthians", CBQ 40 (1978), 574-589; R Jewett, Paul's anthropological terms: A study of their use in conflict settings. Leiden 1971; E Lohse, "Die Berufung auf das Gewissen in der paulinischen Ethik", in Merklein, H (Hrsg), Neues Testament und Ethik: Für Rudolf Schnackenburg,

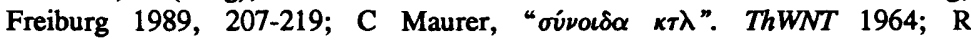
Schnackenburg, Die sittliche Botschaft des Neuen Testaments. Band II, Die urchristlichen Verkundiger, Freiburg 1988; E Schockenhoff, Das umstrittene Gewissen: Eine theologische Grundlegung, Mainz 1990; J Stepien, "Syneidesis (das Gewissen) in der Anthropologie des Apostels Paulus", CoTh 48 (1978),

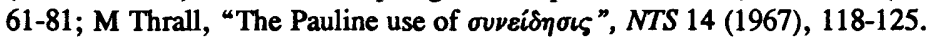

12 Pierce, $a w, 50$.

13 Stelzenberger, $a w, 94-95$.

$14 \quad$ Kyk Jewett, $a w, 415$; Eckstein, $a w, 31$.

15 Sien Eckstein, $a w, 273 \mathrm{e} \mathrm{v}$, wat uiteindelik voorstel dat die frase vertaal kan word met "aus Verantwortung, um der Verantwortlichkeit willen" om die basiese verhouding tussen die indiwidu en sy gewete uit te spel.

16 Stelzenberger, $a w, 33$.

17 Eckstein wy 'n hele afdeling van sy studie aan die woord se gebruik in die "religionsgeschichtliche Bereich", $a w, 35-135$.

18 Dit sal nie deug om die woord met 'n oorkoepelende, maar niksseggende vertaalekwivalent soos "bewussyn" weer te gee nie, pace $\mathrm{R}$ Horsley, $a w, 574$ 589; W L Willis, Idol meat in Corinth: The Pauline argument in 1 Cor 8 and 10, Chico, CA 1985, 89-92; P J Tomson, Paul and Jewish Law: Halakha in the letters of the apostle to the gentiles, Assen 1990, 208-215; P D Gooch, 
Dangerous Food: I Cor 8-10 in its context, Waterloo, Ontario 1993, 87-92, $130,136$.

19 Kyk Stelzenberger, $a w, 44$.

20 'n Verdere voorkoms van die ov́voi $\delta \alpha$ woordgroep is die ontkennende verbale

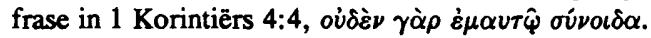

21 Handelinge 23:1; 24:16; 1 Timoteus $1: 5,19 ; 3: 9 ; 2$ Timoteus $1: 3$; Hebreërs 10:22; 13:18; 1 Petrus 3:16, 21.

22 Sappho fr 26.11-12; Sol fr 4.15.

23 Demokr fr 297 DielsVorsokr.

24 Dion Hal Ant 1.78; 8.1.3; 8.48.5; 12.3.1; Diod 4.65.7; 29.25.5. 'n Verdere voorkoms by Dionisios (Thuc 8.22-23) is waarskynlik 'n interpolasie. Twee Menander-fragmente wat die woord bevat ( 81 en 107 Jäkel) is waarskynlik oneg, asook 'n Chrisippos-aanhaling in Diogenes Laertios (7.85.3-4). Die woord kom ook twee maal in die LXX voor: Sap Sal 17:10 en Prediker 10:20; hierdie voorkomste is - soos die lys aanhalings in Stobaios en die verskillende scholia - moeilik dateerbaar.

25 Vergelyk Eur Or 396; Isokr Or 1.16.

26 Vergelyk Diod 4.65.7; 29.25.5-6.

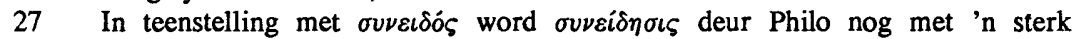
werkwoordelike aspek gebruik, soos blyk uit die feit dat dit telkens met genitiewe gekwalifiseer word; vergelyk Deter 146; Spec 2.49; Virt 124.

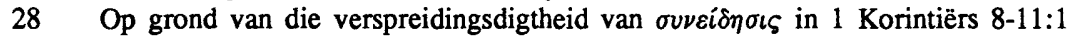
kan aangeneem word dat die Korintiese sterkes die woord in hulle korrespondensie met Paulus opgehaal het; vergelyk Jewett, $a w, 436-439$, wat verskillende betekenisse van die woord by Paulus, die sterkes en die swakkes onderskei.

29 Philo Flac 145; Deus 128; Conf 121; Fug 159.

30 By Philo is daar reeds tekens dat die $\sigma \nu \nu \varepsilon i \delta o ́ \varsigma$ positief or 'n persoon se optrede kan cordeel. Tradisioneel sou dit met die ontkennende verbale frase $\mu \eta \delta \dot{\varepsilon} \nu$

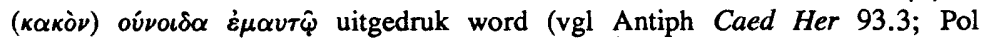
4.86.5). By Philo word die verbale frase se betekenis met die kombinasie

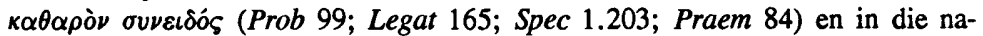

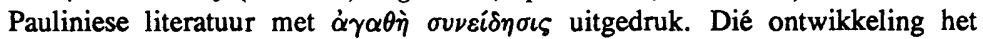
waarskynlik twee oorspronge: die kombinasie $\kappa \alpha \theta \alpha \rho \dot{\alpha} \kappa \alpha \rho \delta i \alpha$, wat in die LXX voorkom as vertaling van die Hebreeus לב טהור (Ps 24:4; $51: 10$ ) en die Latynse gebruik van positiewe adjektiewe saam met conscientia (vgl Quint Inst 2.15.32;

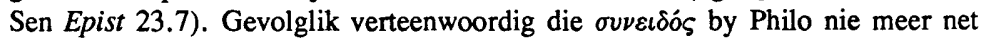
'n denkaksie nie, maar die "ruimte" waarbinne die denkaksie afspeel.

31 Prob 149; Opif 128; Ebr 125; H-J Klauck, "Ein Richter im eigenen Innern: Das Gewissen bei Philo von Alexandrien”, Alte Welt und neuer Glaube: Beiträge zur Religionsgeschichte, Forschungsgeschichte und Theologie des Neuen Testaments. Freiburg Schweiz 1994, 40 verwys na die sintagmatiese eenheid

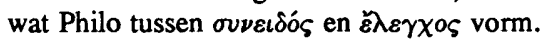

32 Behalwe die bestraffende en pynigende funksies wat die $\varepsilon \bar{\lambda} \varepsilon \gamma \chi 0 \varsigma$ met die

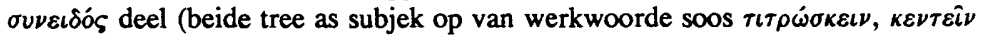

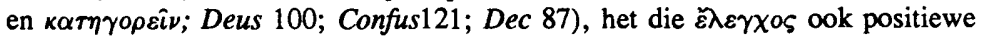
eienskappe: dit kan leer en vermaan (Dec 87; Opif 128), en is voorts daarop gerig om versoening en genesing te bewerkstellig (Deter 146). 


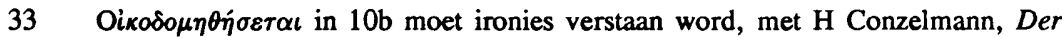
erste Brief an die Korinther:Übersetzt und erklärt, Göttingen 1981, 184 en W Schrage, Der erste Brief an die Korinther. 2 Teilb. (1 Kor 1,1-6,11; 2 Kor 6,12-11,16), Düsseldorf 1995, 265, teen Jewett, $a w, 442$. Dit wil voorkom asof die "sterkes" in die Korintiese gemeente aangevoer het dat hulle kon bydra

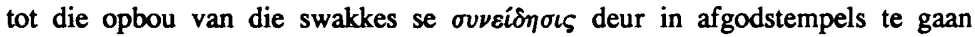
aansit. Paulus verwerp hierdie argument, soos reeds in vers 1 gesien kan word waar hy "opbou" van $\gamma \nu \hat{\omega} \sigma \iota \varsigma$ verwyder en aan $\dot{\alpha} \gamma \dot{\alpha} \pi \eta$ koppel. In vers 10 neem Paulus weer die "opbou" argument van die sterkes op, maar slegs met die doel om dit as ruinosa aedificatio te ontbloot.

34 Van die tipiese werkwoorde wat saam met die oúvoı $\alpha$ woordgroep gebruik word, is $\dot{\varepsilon} \lambda \alpha u ́ \nu \omega$ (Dion Hal Ant 12.3.1); $\tau \alpha \rho \alpha ́ \sigma \sigma \omega$ (Demokr fr 297; Dion Hal

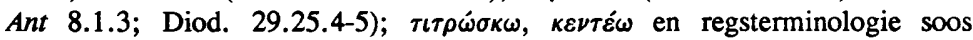

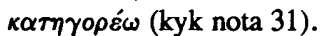

35 Plut Ser Num Vin 554.10.

36 Is Or $8.44 ; 9.20$.

37 Dit kom veral voor by die vroeë Latynse outeurs se gebruik van conscientia, waarvan die Auctor ad Herennium se fisionomie van skuld ( $2.8 \mathrm{e} \mathrm{v})$ die mees uitgebreide voorbeeld is.

38 Philo Flac 7; Deter 23; Poster 59; Deus 128; Spec 1.235; Virt 206; vergelyk H Box, Philonis Alexandrini In Flaccum: Edited with an introduction, translation and commentary. Oxford 1939, 76; Pelletier, a w, 366; D E Marietta, "Conscience in Greek Stoicism", Numen 17 (1971) 178-179; Klauck, $a w, 49$.

39 K $\alpha i$ in Rom 2:15 is epeksegeties (so C E B Cranfield, The Epistle to the Romans Vol 1, Edinburgh 1975, 162; teen U Wilckens, Der Brief an die Römer 1.Teilb. Zürich 1978, 136) sodat die werkwoorde $\kappa \alpha \tau \eta \gamma о \pi \varepsilon \dot{\omega}$ en $\dot{\alpha} \pi \circ \lambda \circ \gamma \varepsilon \dot{\omega} \omega$,

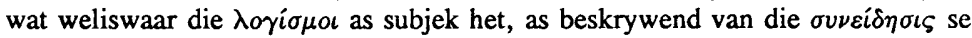
aktiwiteit verstaan moet word.

40 Nêrens word hierdie gedagte met meer poëtiese $\mathrm{krag}$ gestel as in die aanvangsreëls van Psalm 139 nie; kyk ook Psalms 7:10; 17:3-5; 26:2; 38:10; 1 Samuel 16:7; Jeremia 11:20; 17:10; 20:12; Romeine 8:27; 1 Tessalonisense $2: 4$; Handelinge $1: 24 ; 15: 8$.

41 'n Interessante geval is Romeine 9:1, waar Paulus die Heilige Gees wel in

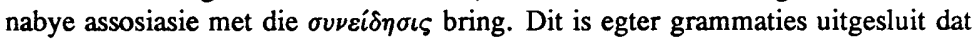
die frase $\dot{\varepsilon} \nu \pi \nu \varepsilon \dot{u} \mu \alpha \tau \iota \dot{\alpha} \gamma i \varphi$ as adjektiwiese beskrywing by $\sigma u \nu \varepsilon i \delta \eta \sigma \iota \varsigma$ verstaan kan word, aangesien die lidwoord $\tau \hat{\eta} \varsigma$ dan na die naamwoord herhaal moes word (vgl Eckstein, $a w, 188$ ). Dit moet dus eerder adverbiaal verstaan word. Geoordeel aan die konteks, is dit waarskynlik dat die Gees ook - parallel aan die

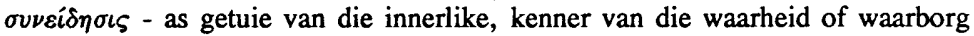
van die waarheid by Paulus se getuienis betrek word.

42 Vergelyk Demokr fr 297; Dion Hal Ant 8.1.3; Diod 29.25.1-6; Philo Dec 86.

43 Die Latynse woord integritas dui op "the undiminished or unimpaired condition of a thing"; "completeness, soundness"; "blamelessness, innocence, integrity", ens (C T Lewis \& C S Short, A Latin Dictionary, Oxford 1975, 973).

46 Vergelyk byvoorbeeld Philo Prob 99; Legat 39; Ios 68; Spec 2.49. 


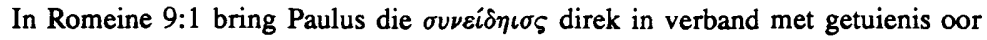
die waarheid, maar hier gaan dit oor waarheid as korrespondensie tussen wat Paulus sê en werklik voel, en hoort daarom eerder by bogenoemde bespreking van persoonlike integriteit en harmonie tussen dink, sê en doen.

48 Gesien die betekenis van die woord oúvol $\delta \alpha$ is die verbintenis natuurlik. Dit is opmerklik dat die woord oúveoıs (insig) in later literatuur sinoniem aan

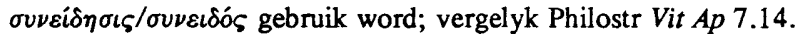

49 Vergelyk Antiph Soph fr 44 A DielsKranz.

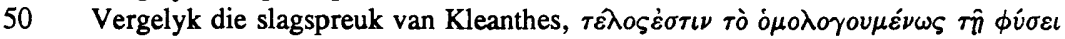

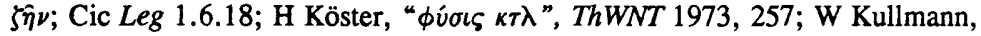
"Antike Vorstufen des modernen Begriffs des Naturgesetzes", in O Behrens \& W Sellert (Hrgs), Nomos und Gesetz: Ursprüngen und Wirkungen des griechischen Gesetzesdenkens, Göttingen 1995, 36-111.

51 Vergelyk veral Philo Abr 5, 275; Kullmann, $a$ w, 64-69 onderskei tussen tipies Stoïsynse en populêre gebruik van die uitdrukking vó o $_{\varsigma} \phi \dot{v} \sigma \varepsilon \omega \varsigma$ by Philo: eg het òf 'n sterk preskriptiewe karakter (wat gedoen of nie gedoen mag word nie) òf dit dui op die reëls wat God vir die kosmos neergelê het, terwyl laasgenoemde dinge soos sorg en liefde vir kinders, heteroseksualiteit en dies meer omskryf.

52 Vergelyk Eckstein, $a w, 314$.

53 Vergelyk Demosthenes (Or 18.263) wat sy opponent Aischines daarvan beskuldig dat hy hom soos 'n haas gedra het omdat hy "met homself geweet het dat hy onreg gedoen het": vreesagtig, bewend, altyd te wagte om geslaan te word.

$54 \quad$ Vergelyk Philo Prob 99; Flac 144; Her 7; Ios 47; Spec 1.203.

55 R Bultmann, Der zweite Brief an die Korinther, Göttingen 1976, 87 e v.

$56 \quad$ Kähler, $a w, 1899,648-649$.

57 Vergelyk Jewett, $a w, 425$; C K Barrett, A commentary on the First Epistle to the Corinthians, London 1968, 195.

58 H Conzelmann, Der erste Brief an die Korinther: Übersetzt und erklärt, Göttingen 1981, 147 besef wel die spontaniteit van die innerlike proses: “Dieser (= die swakke) ist unumgänglich an das Urteil des eigenen Gewissens gebunden, durch dessen Vorhandensein als solches". Hy lei egter daaruit af dat Paulus 'n motivering aanbied waarom die "swak gewete" as geldig aanvaar moet word: "Auch das Urteil des schwachen, ja, des irrenden Gewissens ist gültig. Denn im paulinischen Verstande stellt mich das Gewissen nicht vor eine ideale Norm, sondern konfrontiert den Menschen als den, der er ist, mit der Situation”, Conzelmann, $a w, 182$ nota 16.

59 Vergelyk Klauck, $a w, 30$; K-K Yeo, Rhetorical interaction in 1 Corinthians 8 and 10: A formal analysis with preliminary suggestions for a Chinese, crosscultural hermeneutic, Leiden 1995, 141.

60 W Tarn \& G T Griffith, Hellenistic civilization, London 1974, 332-334.

61 Vergelyk Philo Abr 28-29; Leg Al 1.90-96; Agr 8-9. 